\title{
The Impact of Political Reforms in Improving Quality Health Services: The Case Study of Shamva District
}

\author{
Olivia Gumbo \\ Department of Development Studies, Zimbabwe Open University, Harare, Zimbabwe \\ Email: oliviagumbo@gmail.com
}

How to cite this paper: Gumbo, O. (2019). The Impact of Political Reforms in Improving Quality Health Services: The Case Study of Shamva District. Open Journal of Political Science, 9, 419-433.

https://doi.org/10.4236/ojps.2019.92023

Received: March 8, 2019

Accepted: April 26, 2019

Published: April 29, 2019

Copyright $\odot 2019$ by author(s) and Scientific Research Publishing Inc. This work is licensed under the Creative Commons Attribution International License (CC BY 4.0).

http://creativecommons.org/licenses/by/4.0/

\begin{abstract}
Zimbabweans continue to experience challenges in combating communicable diseases such as tuberculosis, diarrheal diseases, and HIV/AIDS. The country's health sector decentralisation implementation is moving at a snail's speed, triggering complaints of unsatisfactory service delivery at rural health centres. The study examined the impact of political reforms in improving quality health services in Shamva District. The identified political reforms were decentralisation and the second republic that emerged in November 2018 that embraced the 100-day plans approach, civil service reform agenda, development of transitional stabilisation plan and vision 2030 agenda. The study was guided by interpretive and critical post-modernist paradigms. Qualitative methodology was utilised; key informant interviews, focus group discussion and desk reviews were data generation tools that were utilised. The data generated were analysed using grounded theory. The key findings are that decentralisation enabled district health officials to interact with communities through social accountability strategies such as community scorecard, results-based financing and village health worker model that is implemented in Shamva District by Civil Society Organisations. The second republic political reforms enforced the user fee policy in the health sector and focused on improving primary health care. The political reforms led to improved health rights knowledge of communities and quality health services in Shamva District. The study concluded that lack of continuous funding and sustainable plans led to the reversal of positive results that were brought in by the political reforms. The major recommendation is that government should understand that service delivery is not poor by accident; rather it is a symptom of the underlying institutional environment and political economy analysis should be done to address the real blockages in health sector.
\end{abstract}




\section{Keywords}

Political Reforms, Health Services, Community Participation, Empowerment, Accountability

\section{Introduction}

The study was conducted in Shamva District in a bid to understand whether political reforms are improving quality health services. The paper covers the background to the problem, statement of the problem, the purpose of the study, objectives of the study and research questions. The paper further covers the methodology, data analysis, discussion and presentation. The major findings, conclusions and recommendations are also given. The background to the problem is given below.

\subsection{Background to the Problem}

Zimbabwe held her harmonised elections on the 31st of July 2018. The elections were of the President, 201 constituency seats in the National Assembly, and seats in the urban and rural local authorities. These were the country's first elections without the participation of Robert Mugabe, who ruled Zimbabwe for 37 years. Mugabe resigned in November 2017 after receiving pressure from the military, his party and the public giving birth to what is being termed Second Republic. The nature of decentralisation in Zimbabwe kept on changing from administrative to elected local authorities and there have been policy gaps between rhetoric and reality (Wekwete, 1990; Makumbe, 1998; Chakaipa, 2001). There has been lack of decentralisation of power because of various reasons that include unwillingness of national institutions to relinquish power (Conyers, 2003). Post-independence the government of Zimbabwe adopted systems and structures that entrenched exclusion of citizens in policy formulation and development (Kaseke, 1998).

Arnstein, (2011) highlighted that, "participation of the governed in their government is, in theory, the cornerstone of democracy-a revered idea that is vigorously applauded by virtually everyone". This aligns well to the second republic political agenda of bringing people to the centre of development by implementing Zimbabwe Constitution 2013 that advocates for devolution. The health sector in Zimbabwe is not spared from the centralisation and decentralisation administrative challenges. The communities are rarely involved in the development of their rural health centres' plans, there is lack of financial support to improve the health centres and the district staff lack full autonomy to make decisions that might help the rural health centres. Save the Children Report (2016) highlights barriers that communities are facing in accessing provisions of quality Maternal Neonatal and Child Health Services (MNCH). These barriers included, charging of user fees at rural health centres managed by council and at referral hospitals 
under the management of Ministry of Health and Child Care (MoHCC). This excluded the poor people who cannot afford to pay the user fees. There are high levels of commercialisation and unregulated service provision that leads to high out of pocket payments by clients to enable access to health services (Health Finance Policy) (Ministry of Health and Child Care, 2017).

Furthermore, lack of infrastructure that comprise of inadequate water supplies at some Rural Health Centres, poor telephone network and bad roads are barriers that citizens are facing to access health service (Save the Children Report, 2016). In addition, high transport costs to a rural health centre and transferring patients from rural centres to district, provincial or national level discourages citizens from accessing health services. Communities also indicate bad staff attitudes as an element that led many patients to shun medical treatment. Inadequate clinic infrastructure that encourages lack of patient's privacy has also been a deterrent factor for communities to seek health services (Training and Research Support Centre, 2011).

The above-mentioned challenges led to poor quality service delivery and this became a concern to the government and interested partners in health. The Ministry of Health and Child Care therefore signed a Memorandum of Understanding with donors and Civil Society Organisations (CSOs) to help address some of the challenges through implementing different programmes. This prompted the current researcher to examine the impact of political reforms in improving quality health services.

\subsection{Statement of the Problem}

HIV and Sexually Transmitted Infections (STIs) levels in Shamva District were high due to illegal mining activities in the district, resulting in high mobile population or immigrants. The Ministry of Health and Child Care (MoHCC) through the National Health Surveys acknowledges poor health services delivery in rural communities. Lack of full implementation of decentralisation in health services and lack of health discussion platforms between rural communities and state on the quality health service delivery are the main hindrances of quality health services. Adequate governance conditions are critical for sustainable sector development and aid effectiveness.

However, there is lack of evidence on the impact of political reforms in improving quality health services in Zimbabwe. It is not clear whether the political reforms have led the CSOs and the government to increase communities' knowledge on their health rights and entitlements for them to demand quality health services. It is also not clear whether the communities are aware of government's position on sector reforms. Furthermore, it is not clear whether the state is ready to implement the political reforms and has the capacity to handle such reform agendas. Therefore, this study sought to bridge the knowledge gap by examining the impact of political reforms on public health service delivery in Shamva District. 


\subsection{Purpose of the Study}

The purpose of this study was to examine the impact of political reforms in improving quality health services in Shamva District.

\subsection{Objectives of the Study}

The objectives of the study were to:

1) Identify the political reforms Shamva District Health Sector.

2) Explore how the political reforms have been implemented in Shamva District Health Sector.

3) Analyse the impact of the political reforms in Shamva District Health Sector.

\subsection{Research Questions of the Study}

The study's research questions were:

1) Which political reforms have been implemented in Shamva District Health Sector?

2) How were the political reforms implemented by State and CSOs in Shamva District?

3) What are the benefits of political reforms in Shamva District Health Sector?

4) What are the challenges faced by implementing political reforms in Shamva District Health Sector?

5) What are the recommendations that should be considered to embrace political reforms in improving quality health services in Shamva District?

\section{Review of Related Studies}

Political will of partners is expected to facilitate reforms and to improve aid effectiveness (DFID 2005; Williams, Duncan, \& Landell-Mills, 2007; De Haan \& Everest-Phillips, 2007). "Although technical matters remain important, democratic governance has moved to the centre stage in sector operations" (European Commission, 2008). Therefore, understanding of political economy of sector reforms and the factors that have a strong influence on the opportunities for effective reform within the sector and beyond needs to be considered. This aligns with World Bank, (2003) that advocates for the inclusion of the poor in development for them to influence enactment of more pro-poor policies. Furthermore, progressive political parties find ways of how to close gaps and distances between them and the people.

The advantages of considering politics in giving support to social sectors as alluded by the above-mentioned authors show that the support is directed to the root cause of poor service delivery. The political power includes resource allocation and distribution of power which is important in improving service delivery.

The disadvantages of including political reforms in service delivery are that many people will pay more attention to politics and loose focus on its intention to improve service delivery. This links with (Bold, Molina, \& Safir, 2017) views 
that emphasised that the relationship between principal and agent should be to deliver quality public services, although there is growing evidence that the relationship is tending to be for sharing rents accruing from public office rather than to meet service delivery outcomes.

Social accountability strategies that were implemented in Benin, Guinea, Democratic Republic of Congo (DRC), Malawi, Zambia and Lesotho helped these countries' health systems that faced persistent service delivery failures. The expectations of social accountability to offer solutions were very high (Molynuex, Mulupi, Mbabu, \& Marsh, 2012). In all the case studies both the communities and service providers had interface meetings where the community and staff members presented their score sheets results (Ackerman, 2005). All the programmes yielded several results that include improvement in respect for patients where the health officials listen to patients' problems, the health staff are honest, transparent and non-discriminatory in providing supplementary nutrition, there are no favouritism and staff gives priority to serious cases (Shah, 2003; Schaaf, Dumont, Arbesman, \& May-Benson, 2018).

\section{Methodology}

In conducting this study, the researcher used qualitative methodology. The data generating tools used were desk review, focus group discussions and key informant interviews. The data were generated, interpreted, analysed and discussed using qualitative data analysis called grounded theory. Ethical considerations were observed during the data generation.

\subsection{Research Methodology}

The study used interpretive and some elements of critical postmodernist paradigms because of its assumptions and beliefs that are based on qualitative research methodology. The study used purposive sampling to identify the key informants and focus group members. The data were generated from 27 key informants, these experts were from five local rural health centres, district hospital, Non-Governmental Organisations that are active in community health and from the national office of MoHCC. There were 127 participants for focus group discussions from five local health centres. The five health centres identified were named health centre A, B, C, D and E. The community monitors and community literacy facilitators were community representatives who were involved in implementing social accountability programmes in health. Pseudo names were used to keep the confidentiality of the participants and respondents. Table 1 and Table 2 show the pseudonyms used under each data generating tool.

\subsection{Sampling Procedures}

Sampling is when a subset of people from a larger population is selected for the study to represent the population (Gill, Stewart, Treasure, \& Chadwick, 2008; Neuman, 2011). In addition, a sample is the selection of individuals or organisations from 
Table 1. Key informants' demography and pseudonyms.

\begin{tabular}{|c|c|c|}
\hline Facility & Profession & Pseudonyms \\
\hline \multirow[t]{3}{*}{ Health Centre A } & Nurse in Charge & NIC-A \\
\hline & Community Monitor & CM-A1, CM-A2 \\
\hline & Community Literacy Facilitator & CLF-A \\
\hline Health Centre B & Nurse in Charge & NIC-B \\
\hline \multirow[t]{2}{*}{ Health Centre C } & Nurse in Charge & NIC-C \\
\hline & Community Literacy Facilitators & CLF-C \\
\hline \multirow[t]{3}{*}{ Health Centre D } & Nurse in Charge & NIC-D \\
\hline & Community Literacy Facilitator & CLF-D \\
\hline & Councillor & CL \\
\hline \multirow[t]{3}{*}{ Health Centre E } & Nurse in Charge & NIC-E \\
\hline & Community Monitor & CM-E \\
\hline & Community Literacy Facilitator & CLF-E \\
\hline \multirow[t]{3}{*}{ District Hospital } & District Medical Officer & DHE-1 \\
\hline & District Nursing Officer & DHE-2 \\
\hline & Community Sister & DHE-3, DHE-4 \\
\hline Organisation 1 & Executive Director & IP-1 \\
\hline \multirow[t]{2}{*}{ Organisation 2} & Provincial Coordinators & IP-2, IP-3 \\
\hline & Country Director & $1 \mathrm{P}-4$ \\
\hline Organisation 3 & Health Economist & NO-1 \\
\hline Organisation 4 & Social Accountability Officer & IP-5 \\
\hline Organisation 5 & Community Researcher & $\mathrm{NO}-2$ \\
\hline $\mathrm{MoHCC}$ & Director of Policy and Planning & HQ-1 \\
\hline MoHCC & Director of Community Health & HQ-2 \\
\hline Total & & 27 \\
\hline
\end{tabular}

Table 2. Focus group demography and pseudonyms.

\begin{tabular}{cccccc}
\hline Fadlity & Male & Female & & Total & Pseudonyms \\
\hline Health Centre A & 5 & 6 & $\begin{array}{c}\text { Health Centre } \\
\text { Committee Members }\end{array}$ & 11 & HCC-A \\
& & 15 & Village Health Workers & 15 & VHW-A \\
& & 6 & Pregnant Mothers & 6 & PG-A \\
& 1 & 6 & Parents with Children & 7 & PC-A \\
Health Centre B & 3 & 3 & Health Centre Committee & 6 & HCC-B \\
& & 12 & Village Health Workers & 12 & VHW-B \\
& & 7 & Women Getting & 7 & WJ-B \\
Health Centre C & 8 & 3 & Health Centre Committee & 11 & HCC-C \\
& 1 & 5 & Village Health Workers & 6 & VHW-C \\
Health Centre D & 10 & 2 & Health Centre Committee & 12 & HCC-D \\
& 5 & 10 & Village Health Workers & 15 & VHW-D \\
Health Centre E & 7 & 4 & Health Centre Committee & 11 & HCC-E \\
& 0 & 8 & Village Health Workers & 8 & VHW-E \\
Total & 40 & 87 & & 127 & \\
\hline
\end{tabular}


the target population that are used as subjects of the survey, these might not be the population that might be used by the research (Ellis, 2014). In this instance, these are patients who were treated at five rural health centres and at Shamva District hospital. These included parents with children under the age of five years, pregnant mothers and women getting contraceptives.

\section{Deliberate/Purposive Sampling}

Deliberative or purposive sampling is used for the selection of knowledgeable interviewees and experienced focus group participants under the case study. Deliberate sampling is interchangeably referred to as purposive or non-probability sampling. This sampling method is used by selecting particular run that represent the total population in a purposive or deliberate manner (Cozby, 2009). In addition, Ellis (2014) indicates that purposive sampling, "is when you select your participants with a purpose in mind". This links to the current study that used purposive sampling since the researcher selected the 27 experts from the national and district level in health institutions, to be the key informants and 127 participants for 13 focus group discussions.

\section{Ethical Considerations}

Every study needs to consider ethical and legal issues when generating data. The details on how this study handles the ethical issues are elaborated below. This study considered the ethical and legal considerations and developed consent forms that were signed by the respondents and participants before taking part in the research. The ethical and legal issues that were considered include:

Voluntary participation-The researcher sought permission from people before involving them as respondents of key informant interviews and participants of focus group discussions. The respondents and participants were not forced to take part in the research. They were also offered the opportunity to withdraw along the way. Therefore, all of them voluntarily participated. There were two open-ended questionnaires' respondents who refused to take part of study.

Confidentiality and anonymity-Driscoll, (2010) notes that, "participants may reveal embarrassing or potentially damaging information such as racist comments or unconventional behaviour". The researcher protected the identity of participants by creating pseudonyms to protect their identity. Throughout the report pseudonyms were used and this agreed with the participants and respondents. Mashonaland Central had a history of political violence so the participants of FGDs wanted assurance that their names were not going to be published because they did not trust politicians and activists in their areas. The researcher assured them the confidentiality and they signed the consent forms and agreed to take part in the research.

Researcher bias-There is a risk of the researcher to be biased before conducting research. Therefore, the researcher intentionally removed her subjective beliefs and interpreted data accurately. The researcher had verification meetings 
with the KIIs to make sure that she captured the correct information on her thoughts only.

Disclose the truth about researcher's part-The researcher was discreet about her identification, purpose of the study during the data generation process. This enabled the interviewees to respond in an unbiased manner knowing that the research is purely academic not for resource mobilisation or initiating local projects. The researcher also did not disrupt the normal activity of patients and steering committee members during participant observation. This enabled her to pick the correct information from the exercise.

Asking consent for recording audio and taking photos-The researcher asked for consent from participants to record audios during the FGDs which she used for transcribing. The audio helped the researcher to directly quote the respondents and participants. In addition, the researcher asked for permission to take photos for health centres and other relevant photos that were used by the current study.

Accuracy and integrity-The researcher did not fabricate or manipulate data since this is a serious violation of research ethics and can undermine the integrity or aim of the study. The study was accurate and upheld integrity because the researcher went to the field to get data and verified the study's position with participants and respondents.

Approval letters - The researcher was given approval by the MoHCC to conduct the study in Shamva District.

\section{Findings}

The data gathered revealed that the political reforms in Shamva District Health sector were:

1) Decentralisation agenda;

2) Second Republic, this has subcomponents that are:

a) Enforcement of the user fee policy;

b) 100-day plans;

c) Civil service reform;

d) Transitional Stabilisation Programme and Vision 2030;

3) Social accountability programmes.

\subsection{Decentralisation}

HQ-1 indicated that decentralisation in the country was progressing at a slow speed and Ministry of Health and Child Welfare was not spared from that. 1P-1 noted that the decentralised health structures were in place, but they lacked full autonomy and budget to implement their programmes. DHE-1 indicated that they relied on the centre for financial resources and they did not have full autonomy on decision making they needed to consult the headquarters before making some district decisions. He further said, "It is very difficult to operate at district level while waiting for decisions to be made at national level". A good 
example that was given by DHE-1 was of having the Minister of Health and Child Care choosing the final members of community health councils for all 52 districts which showed that the state was still centralised. DHE-2 pointed out that lack of decentralisation made it impossible for district officials to resolve some Village Health Workers grievances because there was unclear chain of command.

\subsection{User Fee Enforcement}

HQ-1 indicated that the government of Zimbabwe passed a user fee policy in 1980 that was fully enforced in December 2017. The user fee policy indicated categories of people who were supposed to get free services at all public health centres these were: pregnant mothers, children under five years, adults above 65 years, HIV and TB patients, people with chronic diseases such as diabetes, war veterans and their beneficiaries and Social Welfare screened patients. DHE-1 pointed out that at all sixteen Shamva District rural health centres, all the patients did not pay for health services. DHE-1 further indicated that Shamva District hospital incurred expenses ranging from $\$ 1500$ to $\$ 2000$ per month for non-paying patients while the hospital collects $\$ 5000$ to $\$ 8000$ from user fees resulting in a funding gap of $\$ 3000$ for the administration expenses of the hospital. DHE-2 echoed that there were late disbursements for national budget allocations. The budget shortfall impacted badly on the quality of services offered at the district hospital. IP-4 highlighted that the user fee policy also distorted the referral system and the district hospital was clogged by non-paying patients.

\subsection{0-Day Plans}

NO-1 indicated that the launch of 100-day plans by the second republic brought a new dimension in the way civil servants should conduct their duties. HQ-2 highlighted that the 100-day plans forced all the departments to indicate their targets and results for the quarter. NO-2 supported that the plans brought accountability in the sector because independent people could track what the Ministry of health and childcare promised to deliver and what they have delivered. On the other hand, DHE-3 expressed that the plans were used as a witch hunt by politicians who are there to find faults of health staff without considering that "we are working with inadequate equipment and resources and this is affecting us mentally and emotionally". IP-2 also indicated that the 100-day plan agenda was quickly losing its momentum because there are no established systems to monitor performance and there are no adequate resources to implement the plans. Therefore, the 100-day plans can evaporate and become a rhetoric in the long run that does not improve quality health services to citizens.

\subsection{Civil Service Reform}

The second republic appointed senior technocrats that lead the civil service reform in the country. These include new commissioners for Public Service Com- 
mission and new members for Health Services Board (HSB). NO-1 indicated that the HSB managed to convince the treasury to uplift their position of freezing new employment in government. The treasury allowed the Ministry of Health and Child Care (MoHCC) to unfreeze 1760 health posts that will enable the health sector to better function. HQ-2 indicated that the unfreezing of post will lift the burden on fewer health staff in Shamva District and the whole nation at large, he went on to say, "the current establishment was done in 1980 when there were less disease burden and fewer people which is different from now where the disease burden and the population has doubled".

\subsection{Transitional Stabilisation Plan and Vision 2030}

The President's State of the nation address (SONA) 2018, signalled that lethargic and non-implementation of Government policies, projects and programmes will no longer be acceptable. He further indicated that bureaucrats must be committed to delivery and that the government will vehemently fight bureaucratic red tape and bottlenecks. The Transitional Stabilisation Plan (2019-2023) highlighted that public-sector reform is fundamental to consolidating democratic transitions and supporting sustainable economic growth, reducing poverty as well as protecting human rights. Zimbabwe Vision 2030 advocate for an ecosystem that delivers basic and non-basic services that are driven by administrative machinery whose values and principles are deeply rooted in the respect, protection, promotion and fulfilment of the fundamental human rights and freedoms of all citizens. HQ-1 indicated that the government position is on improving quality service delivery and MoHCC is not spared from that. Therefore, the Ministry is working towards fulfilling the government's vision of becoming a middle-income country by 2030 . HQ-2 also said universal health is one of the targets that enable the country to achieve its vision.

\subsection{Social Accountability Strategies Implementation}

In advancing community participation and government's responsiveness the district embraced the implementation of social accountability strategies by CSOs. The strategies that emerged from the discussions are captured in Figure 1. These are community scorecard, results-based finance and village health worker model.

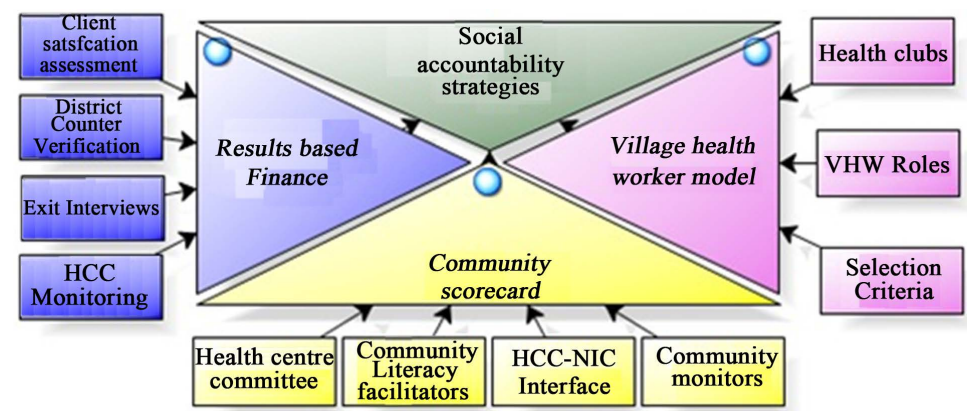

Figure 1. Social accountability strategies implemented in Shamva district. 
IP-1 indicated that community scorecard was implemented under a programme called strengthening community participation in health $(\mathrm{SCPH})$. The programme was implemented by Save the Children International from 2013 to July 2017. HCC-A pointed that the strategy used the interaction of health officials and community representatives to improve quality health services. NIC-A highlighted that the representatives of communities for the programme were the health centre committees (HCCs), community monitors (CM) and community health literacy facilitators (CHL). The other strategy that was highlighted was results-based financing ( $\mathrm{RBF}$ ); this was still being implemented by Crown Agents an international organisation. The programme of RBF started in 2013 and was expected to be fully managed by the Ministry of Health and Child Care in 2020. HQ-2 indicated that in other districts the programme was implemented by Cordaid and the organisation was going to hand over the implementation to the government by end of 2018. IP-3 indicated that the RBF strategy had monitoring tools which are client satisfaction assessment, district counter verification and exit interviews. HCC-C pointed out the HCCs had a management and monitoring role under $\mathrm{RBF}$ programme. Last, but not least, was the village health workers (VHWs) programme, spearheaded by the Ministry of Health and Child Care with support from other international organisations such as the United Nations Children Education Fund (UNICEF) and Save Our Souls (SOS). VHW-E indicated that the VHWs used health clubs and support groups to implement their activities. The NICs indicated that the strategies main objectives were to improve quality health services in the District and this helped the communities and health officials to resolve bottlenecks encountered in delivering quality health services at local level. This indicates that there are limits to how much can be achieved via the "short route" of accountability.

\section{Results}

The political reforms mentioned above had a positive impact on the quality of health services in Shamva District. The description of the first impact is increased health rights knowledge and it is given below.

\subsection{Increased Health Rights Knowledge}

The SAcc strategies increased health rights knowledge to patients where the programme was implemented. HLF-C highlighted that communities were aware of their rights that include right to privacy, confidentiality, choice of medication and consent. PC-A said they understood and knew the importance of balanced nutrition while pregnant and for the growth of the new babies. WJ-B indicated that they had the right to choose the family planning contraceptives of their choice and understood their reproductive rights.

In addition, the CL also highlighted that the rights knowledge led to the reduction of child abuse cases and early marriages although more actions still needed to be done. PC-A said, "we people living with HIV and AIDS and Sexual Transmitted Infections (STIs) we are no longer discriminated against because we 
now know our rights and we are living positively". CM-E indicated that the knowledge opened communities mind and they were respecting the rights of nurses also. HCC-E supported this point, she said before acquiring the knowledge, communities expected nurses to work without taking breaks. Therefore, the SAcc improved the rights knowledge for communities and health officials thereby improved quality of health services delivered to communities.

\subsection{Improved Relations between Health Staff and Communities}

Before the implementation of 100-day plans, SAcc and decentralisation agenda, both the HCCs and nurses acknowledged that there were conflicts and suspicion between them which were hindering quality health service delivery. DHE-3 indicated that the nurses were treated as bosses of health centres, who intimidated patients while patients were viewed as un-informed people. In addition, DHE-4 indicated that "when the SAcc programmes and 100-day implementation started it caused mayhem in the district, the nurses felt challenged by the programme, but, latter became comfortable with the programme". The programme enabled the two parties to reconcile.

The NIC-E indicated that they had good relations with their HCC members and the discussions they had on issues raised by communities through community scorecard helped them to iron out some outstanding challenges. She went on to say "the HCC stand for us when there were challenges with politicians, they came into our shoes and protected us. We were fully represented by them to communities and they also fully represented the communities to us". The engagement of communities and nurses at health centre level yielded good results which contributed to quality health service provision.

\section{Challenges}

There were challenges that were identified during the implementation of political reforms in Shamva District.

\subsection{Lack of Feedback Documentation by Community Representatives}

The study gathered that there were minutes for the meetings that were conducted between the HCCs and health officials at local and district level that were used at provincial, national level and to donors for administration purposes. However, there was lack of evidence that showed HCCs were giving feedback to communities on the progress made on their demands. The feedback might be happening in an uncoordinated way. However, HCCs failed to prove their feedback mechanisms. Lack of documentation can be a challenge in compiling the successes and failures of political reforms in the health sector.

\subsection{Poor Sustainable Plans}

Volunteerism in Shamva District where people were struggling to make ends meet led some community monitors and community literacy facilitators not to 
continue after the end of the SAcc programme funding. Non-involvement of local leaders on training of health rights and other health-related issues contributed to failure of the programmes after the end of external funding.

\subsection{Lack of Policy Influence}

The SAcc programme and lack of full decentralisation led the successes at local level not to link up with strategic policy change. Positive results of the reforms in some areas in the district did not cascade to other health centres in the same district nor changed any district policy.

\subsection{Lack of Full Decentralisation}

Lack of fiscal decentralisation and full autonomy at district level hampered the implementation of the political reforms in the health sector. The district health executives indicated that this was handicapping them from offering quality health services.

\section{Discussion}

The findings indicate that political reforms in Shamva District led to the improvement of quality health services offered although there were reports of inadequate supply of material and resources in the public sector. This makes it impossible for civil servants to work efficiently and meet expectations. The user fee policy helped the rural communities to access free services. On the other hand, there were reports of non-availability of drugs that the patients were supposed to buy. This can be referred to as "free but not free services" for the poor. The rhetoric of full decentralisation, devolution mantra by the government officials did not translate to reality at district level.

\section{Conclusion}

The findings of the study covered above informed the conclusions of this study. The researcher concluded that cosmetic participation of community representatives especially the HCCs was there to fulfil donor conditions. The researcher concluded that there was transactional relationship between the HCCs and NICs not genuine dialogues on community's needs.

The researcher further concluded that without financial resources and sustainable plans the political reforms did not yield purported results. Instead the programmes somehow created more donor dependency.

\section{Recommendations}

The researcher proposes recommendations to health sector stakeholders in Shamva District. These are given below.

\section{1) Linking local programmes to strategic policy issues}

It is recommended that government officials and implementing organisations should link up tactical and strategic programmes to influence the Shamva Dis- 
trict communities to advocate and lobby for pro-poor policies that are relevant to them. Currently, Shamva District inputs are rarely linked to national decisions.

\section{2) Capitalizing on the use of both organic and induced programming}

It is recommended that Shamva District Health Sectors use a mixture of short route and long route accountability approaches. Mixed approach can sustain programmes beyond donor funding withdrawal. It is recommended that burial societies and community clubs' systems be used for sustainability.

3) Importance of documentation of evidence

It is recommended that communities be trained on gathering evidence for their proposed programmes for them to get financial support since facts are the ones that convince donors not emotions without evidence attached.

\section{Acknowledgements}

I want to acknowledge the Shamva District health personnel who were welcoming and enabled me to gather data from their community members. They gave me valuable information for this research.

\section{Conflicts of Interest}

The author declares no conflicts of interest regarding the publication of this paper.

\section{References}

Ackerman, J. M. (2005). Human Rights and Social Accountability. Social Development Papers No. 86, Washington DC: The World Bank.

Arnstein, S. R. (2011). A Ladder of Citizen Participation. Journal of the American Planning Association, 35, 216-224.

Bold, T., Molina, E., \& Safir, A. (2017). Clientelism in the Public Sector: Why Public Service Reforms May Not Succeed and What to Do about It. World Development Report 2017 Governance and the Law. https://doi.org/10.1596/26257

Chakaipa, S. (2001). The Zimbabwean Experience. In D. Conyers (Ed.), African Regional Conference on the challenge of Decentralisation and Local Government. Cape Town: United Nations Capital Development Funds.

Conyers, D. (2003). Decentralisation in Zimbabwe: A Local Perspective. https://doi.org/10.1002/pad.265

Cozby, P. C. (2009). Methods in Behavioural Research (10th ed.). New York: McGraw Hill.

De Haan, A., \& Everest-Phillips, M. (2007). Can New Aid Modalities Handle Politics (Vol. 63)? WIDER Research Paper, Helsinki: UNU-WIDER.

DFID (2005). Lessons Learned-Planning and Undertaking a Drivers of Change Study. How to Note, A DFID Practice Paper, London: DFID.

Ellis, J. (2014). Writing Better Questionnaires: Getting Better Data. Charities Evaluation Services.

European Commission (2008). Analysing and Addressing Governance in Sector Operations. Tools and Methods Series, Reference Document No. 4. 
Gill, K., Stewart, E., Treasure, B., \& Chadwick, B. (2008). Methods of Data Collection in Qualitative Research: Interviews and Focus Groups. British Dental Journal, 204, 291-295. https://doi.org/10.1038/bdj.2008.192

Kaseke, E. (1998). The State and Dynamics of Social Policy Practice and Research in Zimbabwe. Journal of Social Development in Africa, 13, 21-34.

Makumbe, J. (1998). Development and Democracy in Zimbabwe: Constraints of Decentralization. Zimbabwe: Sapes Trust.

Ministry of Health and Child Care (2017). Zimbabwe Health Financing Policy.

Molynuex, S., Mulupi, S., Mbabu, L., \& Marsh, V. (2012). Benefits and Payment for Research Participants: Experiences and Views from a Research Centre on the Kenyan Coast. Kenya: BMC Medical Ethics Bio Med Central Ltd.

Neuman, W. L. (2011). Social Research Methods-Qualitative and Quantitative White Water. Madison, WI: University of Wisconsin.

Save the Children Report (2016). Quarter 11 Report on Strengthening Community Participation in Health. Save the Children International.

Schaaf, R. C., Dumont, R. L., Arbesman, M., \& May-Benson, T. A. (2018). Efficacy of Occupational Therapy Using Ayres Sensory Integration. US National Library of Medicine National Institutes of Health.

Shah, M. (2003). Using Community Scorecards for Improving Transparency and Accountability in the Delivery of Public Health Services: Experience from Local Initiatives for Health (LIFH) Project. Malawi: CARE International.

Training and Research Support Centre (TARSC) (2011). Supporting the Role of the Health Centre Committees. A Training Manual. Revised Edition 2016, Harare: TARSC.

Wekwete, K. H. (1990). Constraints to Planning for Socialism in Zimbabwe. Gower Publishing Company Limited.

Williams, G., Duncan, A., \& Landell-Mills, P. (2007). Making the New Political Economy Perspective More Operationally Relevant for Development Agencies. Policy Practice Brief No. 2, Brighton: The Policy Practice.

World Bank (2003). A User's Guide to Poverty and Social Impact Analysis. Washington DC: World Bank.

Zimbabwe Constitution 2013. Harare: Government Printers. 